\title{
MEMBANGUN RELASI KOMUNIKASI KELUARGA DALAM MEMBENTUK SIKAP SOSIAL REMAJA
}

\author{
Mahdi, Masdudi \\ IAIN Syekh Nurjati Cirebon \\ mahdiahmad2508@gmail.com, masdudi.bandung@gmail.com
}

\begin{abstract}
Hubungan yang baik dalam sebuah keluarga adalah hubungan yang penuh pengertian dan kasih sayang, disertai dengan bimbingan dan dorongan dari orang tua. Setiap anggota keluarga harus saling menghormati, saling memperhatikan dan saling memberi tanpa harus diminta, dan juga setiap masalah harus dihadapi dan diupayakan untuk kemudian dipecahkan bersama, serta memberi kebebasan kepada anak untuk mengungkapkan pikiran dan perasaanya. Atas dasar sikap saling mempercayai, saling membantu, membimbing anak dan berkomunikasi dalam keluarga, anak akan merasa memiliki kepercayaan diri yang tinggi serta mampu mengembangkan dirinya, sehingga dapat bersosialisasi dengan masyarakat sekitar. semua pengalaman yang dilalui oleh anak sejak lahir merupakan unsur-unsur dalam membentuk sikap serta pribadi anak. Dengan dilatar belakangi situasi keluarga yang beragam, serta lingkungan yang berbeda maka akan menghasilkan sikap dan perilaku yang beragam dan berbeda pula. Dalam rangka mengarahkan pertumbuhan dan perkembangan yang dialami anak, diperlukan figur seorang pendidik yang mampu berperan dalam pembentukan sikap sosial anak, termasuk anggota keluarga dalam hal ini yang paling dominan adalah orang tua. Kenyataan ini patut menjadi perhatian bagi orang tua sebab, apabila menginginkan anaknya tumbuh dengan mencontoh kebiasan-kebiasan yang baik dan etika mulia semuanya harus dimulai dalam lingkungan keluarga.
\end{abstract}

\section{Kata Kunci : Komunikasi, Keluarga dan Sikap Sosial}

\begin{abstract}
A good relationship in a family is a relationship full of understanding and affection, accompanied by guidance and encouragement from parents. Every family member must respect each other, mutual pay attention and give to each other without having to be asked, and also every problem must be faced and sought to then be solved together, as well as giving freedom to children to express their thoughts and feelings. On the basis of mutual trust, mutual assistance, guiding children and communicating in the family, children will feel they have high confidence and are able to develop themselves, so they can socialize with the surrounding community. all the experiences that the child has passed from birth are elements in shaping the child's attitude and personality. With a background of diverse family situations, as well as different environments, it will produce attitudes that are diverse and different. In order to direct the growth and development experienced by children, we need a figure of an educator who is able to play a role in shaping the social attitude of children, including family members, in this case the most dominant is parents. This fact should be a concern for
\end{abstract}

The journal of social and economics education 
parents because, if they want their children to grow by copying good habits and noble ethics everything must start in the family environment.

\section{Keywords: Communication, Family and Social Attitudes}

\section{A. PENDAHULUAN}

\section{1) Latar Belakang Masalah}

Manusia adalah makhluk Allah yang telah diciptakan dalam bentuk yang paling indah dan dilengkapi dengan berbagai atribut yang membedakan antara manusia dengan makhluk ciptaan Allah lainnya. Identitas manusia sebagai makhluk sosial mengharuskan manusia berhubungan dengan orang lain. Dengan kata lain manusia tidak dapat hidup sendiri, manusia mempunyai hubungan interdependensi, baik secara langsung maupun tidak langsung dengan pihak lain. Dalam interaksi atau berhubungan dengan orang lain, manusia memerlukan sarana berupa komunikasi. Sebuah penelitian mengungkapkan bahwa $70 \%$ waktu bangun kita digunakan untuk berkomunikasi (Ngainun Naim, 2011: 15).

Komunikasi menjadi bagian yang erat dalam kehidupan manusia. Sebagian besar kehidupan manusia diisi dengan komunikasi, baik dengan anggota keluarga, teman, tetangga, sejawat, maupun dengan diri sendiri. Dengan komunikasi manusia akan dapat memenuhi segala kebutuhan hidupnya, baik kebutuhan lahir maupun kebutuhan batin. Lewat komunikasi, manusia bisa saling tukar informasi, berbagi, mengembangkan diri, dan berbagai manfaat lainnya.

Makna penting komunikasi sesungguhnya telah menjadi kesadaran yang luas di masyarakat. Hal ini dibuktikan dengan kehidupan keseharian yang selalu diisi dengan kegiatan komunikasi. Namun, tingkat kesadaran dan implementasinya masing-masing orang berbeda. Ada yang kesadarannya sudah tinggi dan didukung dengan pemahaman yang baik tentang komunikasi. Ada juga yang kesadarannya rendah. Komunikasi apabila dilakukan secara tepat akan membawa hasil yang sesuai dengan harapan. 
Sebaliknya, komunikasi yang kurang tepat bisa membawa efek negatif (Ngainun Naim, 2011: 7).

Menurut Abu Ahmadi (2002: 87) keluarga adalah kelompok pertama dan utama yang di kenal anak dalam kehidupannya. Hal ini di karenakan anak sebelum melakukan interaksi dengan lingkungannya yang lebih luas di luar lingkungan keluarga maka anak terlebih dahulu belajar dan melakukan interaksi atau komunikasi dengan anggota keluarganya. Zakiyah Daradjat (1994: 56) menyatakan bahwa semua pengalaman yang dilalui oleh anak sejak lahir merupakan unsur-unsur dalam membentuk sikap serta pribadi anak. Dengan dilatar belakangi situasi keluarga yang beragam, serta lingkungan yang berbeda maka akan menghasilkan sikap dan perilaku yang beragam dan berbeda pula.

Anak merupakan individu yang sedang mengalami perkembangan dan memerlukan pembinaan secara kontinu dan terarah yang positif, hal ini tidak lain karena anak adalah merupakan tanggung jawab orang tua. Hal ini sebagaimana yang terdapat dalam surat At Tahrim ayat 6:

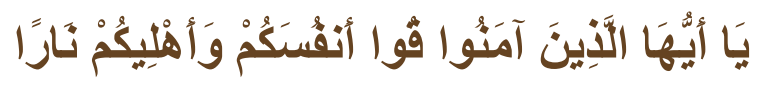

Artinya: "Hai orang- orang yang beriman peliharalah dirimu dan keluargamu dari api neraka."(Q.S. At-Tahrim: 6)

Komunikasi dalam keluarga memberikan efek perubahan sikap, pendapat, perilaku ataupun perubahan secara sosial. Perubahan sikap bisa berupa sikap positif maupun negatif. Sikap terlihat dari tanggapan seseorang apakah ia menerima atau menolak, setuju atau tidak setuju terhadap obyek atau subyek. Perubahan pendapat tersebut diperoleh dari penciptaan pemahaman. Dalam pemahaman disini keluarga memberikan suatu cara berkomunikasi agar terbentuk sikap sosial anak ke arah yang lebih baik. Dimana sikap merupakan suatu kecenderungan untuk mendekat atau menghindar, positif atau negatif terhadap berbagai keadaan sosial, apakah itu institusi, pribadi, situasi, ide, konsep dan sebagainya (Gerungan, 2000: 149). 
Remaja kerap diartikan masa pergaulan yang menyenangkan dan kadang membingungkan sehingga arah dan tujuan remaja masih mengikuti emosional sesaat tanpa memandang efek negatif dari tindakan tersebut. Banyak remaja berpendapat bahwa remaja patut dihargai dan mendapat dukungan penuh dari setiap tindakan yang mereka anggap paling benar. Pada prinsipnya saat memasuki masa remaja, sangat rentan menemukan hal-hal baru. Dimana hal-hal baru tersebut tak luput dari kenakalan remaja itu sendiri.

Kenakalan remaja dapat berakar pada kurangnya dialog dalam masa kanak-kanak dan masa berikutnya, karena orangtua terlalu menyibukkan diri, sedangkan kebutuhan yang lebih mendasar yaitu cinta kasih diabaikan. Akibatnya anak menjadi terlantar dalam kesendirian dan kebisuannya. Ternyata perhatian orangtua dengan memberikan kesenangan materil belum mampu menyentuh kemanusiaan anak. Dialog tidak dapat digantikan kedudukannya dengan benda mahal dan bagus.

Selain itu, anak-anak remaja umumnya merasa kesepian karena kurangnya komunikasi dengan orang tua mereka. Hal ini yang mendorong mereka untuk menarik perhatian orang tua mereka dengan melakukan berbagai hal. Mayoritas anak-anak remaja akan bersikap menjadi anak yang nakal. Bahkan cenderung melakukan perilaku yang penyimpangan seperti: penggunaan obat-obatan terlarang, tawuran antar kelompok, serta berbagai masalah pribadi dan sosial lainnya yang muncul dalam kehidupan sehari-hari. Seperti: sikap individualis, egois, acuh tak acuh, kurangnya rasa tanggung jawab, malas berkomunikasi dan berinteraksi atau rendahnya empati merupakan fenomena yang menunjukkan adanya kehampaan nilai sosial.

\section{2) Rumusan Masalah}

Berdasarkan latar belakang masalah tersebut dapat dirumuskan pertanyaan penelitian sebagai berikut:

a. Bagaimana komunikasi yang dilakukan dalam keluarga?

b. Bagaimana sikap sosial anak remaja? 
c. Seberapa besar pengaruh komunikasi dalam keluarga terhadap sikap sosial anak remaja?

\section{3) Tujuan}

Tujuan penelitian dalam skripsi ini adalah untuk memperoleh data tentang:

a. Komunikasi yang dilakukan dalam keluarga

b. Sikap sosial anak remaja

c. Besarnya pengaruh komunikasi dalam keluarga terhadap sikap sosial anak remaja.

\section{B. KAJIAN TEORI}

\section{1) Konsep dan Dimensi Komunikasi Dalam Keluarga}

Pengertian komunikasi secara etimologi, berasal dari kata Latin Cum, yaitu kata depan yang berarti dengan dan bersama dengan, dan unus, yaitu kata bilangan yang berarti satu. Dari kedua kata itu terbentuk kata benda communio yang dalam bahasa Inggris menjadi communion dan berarti kebersamaan, persatuan, persekutuan, gabungan, pergaulan, hubungan (Ngainun Naim, 2011: 17).

Definisi komunikasi secara terminologi menurut A.W Widjaja, (1997: 8) adalah penyampaian informasi dan pengertian dari seseorang kepada orang lain. Komunikasi dikatakan berhasil apabila sekitarnya timbul saling pengertian yaitu jika kedua belah pihak (si pengirim dan penerima) informasi dapat saling memahami.

Sarlito W.S, (2000: 86) mengatakan bahwa komunikasi adalah proses pengiriman berita dari seseorang kepada orang lain. Syarat pertama untuk terjadinya komunikasi adalah adanya dua orang atau lebih. Maka dapat disimpulkan bahwa komunikasi merupakan proses penyampaian informasi baik berupa pesan/berita yang melibatkan dua orang atau lebih, yang terdiri dari komunikan (pendengar/penerima berita/informasi) dan komunikator (pembicara/pengirim berita/informasi) yang secara bergantian memberikan 
informasi dalam suatu hubungan atau kontak yang terjadi di antara keduanya, sehingga di hasilkan suatu pemahaman atas apa yang di bicarakan.

Sahid Athar, (2003: 47) mengatakan bahwa keluarga ialah suatu tipe struktur khusus yang prinsip-prinsipnya berkaitan satu sama lain melalui ikatan-ikatan darah dan atau hubungan perkawinan, dan yang hubunganhubungannya bersifat fitri yang meminta ekspektasi timbal balik yang di tentukan oleh agama di realisasikan oleh hukum dan diinternalisasikan oleh individu.

Menurut Moh Schohib dalam Ngainun Naim, (2011: 201) keluarga adalah sekumpulan orang yang hidup bersama dalam tempat tinggal bersama dan masing-masing anggota merasakan adanya pertautan batin sehingga terjadi saling mempengaruhi dan saling memperhatikan.

Berbekal pengertian keluarga di atas penulis dapat memberikan pengertian keluarga sebagai suatu kelompok terkecil dalam masyarakat yang terdiri dari ayah, ibu dan anak-anaknya juga orang lain yang masih ada atau tidak ada pertalian darah dan bertempat tinggal dalam satu rumah serta terjadi hubungan timbal balik diantara satu sama lain.

Komunikasi keluarga adalah komunikasi/interaksi yang terjadi diantara orang tua dengan anak dalam rangka memberikan kesan, keinginan, sikap, pendapat, dan pengertian, yang dilandasi rasa kasih sayang, kerja sama, penghargaan, kejujuran, kepercayaan dan keterbukaan diantara mereka.

Berkaitan dengan pentingnya komunikasi, Deddy Mulyana (2003: 5) mengatakan bahwa orang yang tidak pernah komunikasi dengan manusia bisa dipastikan akan tersesat karena ia tidak berkesempatan menata dirinya dalam suatu lingkungan sosial. Komunikasilah yang memungkinkan individu membangun suatu kerangka rujukan dan menggunakannya sebagai panduan untuk menafsirkan situasi apapun yang ia hadapi. Komunikasi pula yang memungkinkannya mempelajari dan menerapkan strategi-strategi adaptif untuk mengatasi situasi-situasi problematik yang ia masuki. Tanpa melibatkan dalam komunikasi, seseorang tidak akan tahu bagaimana makan, minum, berbicara 
sebagai manusia dan memperlakukan manusia lain secara beradab, karena caracara berperilaku tersebut harus dipelajari lewat pengasuhan keluarga dan pergaulan orang lain yang intinya adalah komunikasi.

Komunikasi yang terjadi kebanyakan adalah komunikasi kelompok yang bertukar pikiran, informasi, pengatuan dan dapat pula terjadi perubahan sikap dan perilaku. Seperti halnya komunikasi yang terjadi dalam lingkungan keluarga merupakan salah satu contoh dari komunikasi kelompok.

Menurut Charles Horton Cooley yang dikutip Jalaludin Rahmat (1994: 142) mengatakan bahwa komunikasi dalam keluarga merupakan komunikasi kelompok primer, karena terdapat keterkaitan emosional diantara komunikan dan komunikatornya, sehingga komunikasi lebih dekat, lebih personal, lebih menyentuh hati serta bersifat dalam dan meluas hingga mengungkapkan unsurunsur perilaku serta kepribadian anggotanya.

Hubungan yang baik dalam sebuah keluarga adalah hubungan yang penuh pengertian dan kasih sayang, disertai dengan bimbingan dan dorongan dari orang tua. Setiap anggota keluarga harus saling menghormati, saling memperhatikan dan saling memberi tanpa harus diminta, dan juga setiap masalah harus dihadapi dan diupayakan untuk kemudian dipecahkan bersama, serta memberi kebebasan kepada anak untuk mengungkapkan pikiran dan perasaanya. Indikator/dimensi dari komunikasi dalam keluarga:

\section{a. Keterbukaan}

Adalah kemampuan untuk membuka atau mengungkapkan pikiran, perasaan, dan reaksi kita kepada orang lain. Kita harus melihat bahwa diri kita dan pembukaan diri yang akan kita lakukan tersebut diterima orang lain, kalau kita sendiri menolak diri kita (self rejecting), maka pembukaan diri kita akan kita rasakan terlalau riskan. Keterbukaan di sini adalah bersikap terbuka dan jujur mengenai perasaan/pemikiran masing-masing, tanpa adanya rasa takut dan khawatir untuk mengungkapkannya (Alo Liliweri, 1997 : 18).

\section{b. Empati}


Empati merupakan kemudahan dalam melakukan komunikasi yang baik. Komunikasi yang baik antara orang tua dengan anak akan menjadikan anak merasa dihargai sehingga anak akan merasa bebas mengungkapkan perasaan serta keinginannya.

\section{c. Dukungan}

Ada beberapa prinsip yang dapat digunakan dalam mendukung komunikasi keluarga, sehubungan komunikasi antar orang tua dengan anakanak.

1) Bersedia memberikan kesempatan kepada anggota keluarga yang lain sehingga pihak lain berbicara.

2) Mendengarkan secara aktif apa yang dibicarakan pasangan bicara.

3) Mengajari anak-anak untuk mendengarkan.

4) Menyelesaikan konflik secara dini sehingga terjalin komunikasi yang baik.

\section{d. Perasaan Positif}

Bila kita berpikir positif tentang diri kita, maka kita pun akan berpikir positif tentang orang lain, sebaliknya bila kita menolak diri kita, maka kitapun akan menolak orang lain. Bila kita memahami dan menerima perasaanperasaaan kita, maka biasanya kitapun akan lebih mudah menerima perasaanperasaan sama yang ditunjukkan orang lain.

\section{e. Kesamaan}

Sebuah komunikasi akan dikatakan sukses kalau komunikasi tersebut menghasilkan sesuatu yang diharapkan yakni kesamaan pemahaman. Kemampuan orang tua dalam melakukan komunikasi akan efektif karena orang tua dapat membaca dunia anaknya (selera, keinginan, hasrat, pikiran, dan kebutuhan), (Alo Liliweri, 1997 : 13).

Kunci penting dalam menjalankan komunikasi secara efektif menurut Ngainun Naim, yang harus diterapkan dalam keluarga diantaranya:

a) Respect, adalah sikap menghargai terhadap setiap individu yang menjadi sasaran pesan yang disampaikan. 
b) Empathy, adalah kemampuan seseorang dalam menempatkan dirinya sesuai dengan situasi atau kondisi yang dihadapi oleh orang lain.

c) Audible, adalah dapat didengarkan atau dimengerti dengan baik.

d) Clarity, selain pesan harus dapat dimengerti dengan baik, kejelasan pesan juga harus mendapatkan perhatian sehingga tidak menimbulkan multiinterprestasi.

e) Humble, Sikap ini merupakan unsur yang terkait dengan hukum pertama untuk membangun rasa menghargai orang lain yang biasanya didasari oleh rendah hati. (Ngainun Naim, 2011: 47).

Alo Liliweri, (1997: 6) menjelaskan ruang lingkup komunikasi keluarga terdiri atas unsur-unsur: Bentuk, sifat, metode, fungsi, dan tujuan. Unsur-unsur tersebut dalam kaitannya dengan komunikasi keluarga diuraikan sebagai berikut:

a). Bentuk komunikasi dalam keluarga adalah personal communication yaitu komunikasi antar pribadi.

b). Sifat komunikasi dalam keluarga dapat verbal maupun non verbal.

c). Metode komunikasi dalam keluarga adalah informasi, persuasive, dan instruktif.

d).Fungsinya adalah untuk memberikan informasi, edukasi, persuasi, dan hiburan.

e).Tujuan komunikasi dalam keluarga adalah perubahan sosial, partisirasi sosial, perubahan sikap, perubahan opini dan juga perubahan tingkah laku.

\section{2) Relasi Komunikasi dalam Keluarga}

Dalam sebuah keluarga komunikasi juga mempunyai peranan yang tidak sederhana. Hal ini tidak lain karena keluarga adalah merupakan kumpulan manusia yang biasanya paling tidak terdiri dari seorang suami, seorang istri dan anak. Bagi sebuah keluarga komunikasi adalah merupakan suatu kebutuhan karena dengan komunikasilah seorang suami dan istri dapat berbagi rasa dan memberikan saling pengertian, sehingga dua individu itu dapat berjalan seiring 
dan selaras. Sedangkan komunikasi bagi anak adalah suatu kebutuhan dalam rangka menciptakan dirinya menjadi manusia yang normal.

Dengan memperhatikan hal ini, Jalaluddin Rahmat (1992: 14) mengatakan ada dua hal yang menunjukkan pentingnya fungsi komunikasi, yaitu:

a. Komunikasi amat esensial buat pertumbuhan kepribadian manusia.

b. Komunikasi amat erat kaitanya dengan perilaku dan kesadaran manusia.

Hafied Cangara, (2002: 62) menjelaskan fungsi komunikasi dalam keluarga ialah meningkatkan hubungan insani (Human relation), menghindari dan mengatasi konflik-konflik pribadi dalam keluarga, mengurangi ketidak pastian sesuatu, serta berbagi pengetahuan dan pengalaman dengan orang lain.

Menurut Deddy Mulyana, (2003: 3) fungsi komunikasi dalam keluarga diantaranya: mempererat hubungan antara anggota keluarga, menanamkan sikap percaya diri dan jujur, mewariskan dan memelihara nilai-nilai yang dianut dalam keluarga, memperkenalkan konsep diri anggota keluarga, menunjukkan eksistensi diri anggota keluarga, melatih hidup bermasyarakat, untuk memenuhi kebutuhan emosional. Atas dasar sikap saling mempercayai, saling membantu, membimbing anak dan berkomunikasi dalam keluarga, anak akan merasa memiliki kepercayaan diri yang tinggi serta mampu mengembangkan dirinya, sehingga dapat bersosialisasi dengan masyarakat sekitar (Utami Munandar, 1992: 47).

Hal terpenting dalam melakukan komunikasi adalah dapat menciptakan suasana yang efektif. Secara sederhana komunikasi dikatakan efektif apabila orang berhasil menyampaikan apa yang dimaksudnya dan dapat dipahami oleh orang yang mendengarkan. Pada umumnya komunikasi dinilai efektif bila pesan yang disampaikan oleh pengirim berkaitan erat dengan rangsangan yang ditangkap dan dipahami oleh penerima, walaupun belum sampai pada kesepakatan hanya sekedar dipahami. Seperti yang dikemukakan oleh Deddy Mulyana, (1999: 38) bahwa komunikasi efektif adalah komunikasi yang memungkinkan makna yang disampaikan mirip atau sama dengan yang 
dimaksudkan komunikator, singkatnya komunikasi efektif adalah makna bersama.

Komunikasi yang efektif dalam dalam keluarga akan menghasilkan generasi yang kepribadian sesuai harapan keluarga. Diantara komunikasinya berupa pengawasan, perhatian dan mencontohkan sesuatu yang langsung dilaksanakan oleh kedua orang tuanya, maka anak-anak akan mencontoh kebijaksanaan dan kebiasaan orang tuanya. Oleh karena itu pendidikan dalam keluarga dapat dikatakan sebagai dasar kesuksesan pembentukan pribadi anak. Keuntungan dari pelaksanaan komunikasi bukan saja orang tua yang mengajari anak tetapi bisa juga sebaliknya yaitu anak-anak akan mengajari orang tuanya tentang hal-hal yang dialaminya melalui percakapan yang terjadi diantara mereka.

Komunikasi keluarga efektif tidak bisa lepas dari karakter dan fungsi dari hubungan antara orang tua dengan anaknya. Komunikasi keluarga merupakan unsur yang berperan dalam pembentukan kepribadian anggota keluarga khususnya anak. Kegiatan komunikasi keluarga yang efektif yaitu jelas, singkat, lengkap, mudah dimengerti, tepat dan saling memperhatikan, dapat membentuk gaya hidup dalam keluarga yang sehat. Dampak situasi hubungan yang sehat antara orang tua dengan anak, yaitu komunikasi yang penuh kasih sayang, persahabatan, kerjasama, penghargaan, kejujuran, kepercayaan, dan keterbukaan akan membentuk ketentraman keluarga. suasana komunikasi yang demikian merupakan suasana yang menggairahkan bagi pertumbuhan anak.

\section{3) Faktor-Faktor yang Mempengaruhi Komunikasi Efektif}

Menjalin komunikasi yang baik merupakan keahlian yang dapat dipelajari, karena manusia tidak dilahirkan dengan keahlian tersebut. Melainkan melalui pengalaman hidup seseorang keahlian tersebut diperoleh. Kita mendapat pelajaran tentang berkomunikasi dari lingkungan keluarga yaitu dari bapak, ibu, dan anggota keluarga yang lain. Dilingkungan sekolah dengan para guru, teman juga masyarakat sekitar tempat tinggal. Dalam lingkungan keluarga hal terpenting untuk mengembangkan bakat berkomunikasi yaitu 
dengan cara memberikan kebebasan untuk menyatakan pandangan, perasaan, dan gagasan-gagasan.

Menurut Darlene P. Hopson dan Derek S. Hopson (2002: 106) mengatakan bahwa ada beberapa hal penting dalam memupuk keahlian untuk berbicara dan mendengarkan anak, diantaranya:

a. Selalu mendengarkan secara aktif, hal ini akan membantu meningkatkan rasa percaya diri anak dalam mengungkapkan sesuatu. Hal itu juga akan mengajarkan kepada mereka bahwa kita menghormati mereka.

b. Berikan jawaban yang terbuka, karena jawaban yang tertutup cenderung menutup peluang komunukasi lebih lanjut, sementara jawaban yang terbuka membuka peluang komunikasi.

c. Menggunakan kata "saya" lebih baik daripada "kamu", hal itu demi menjaga emosi anak juga untuk meningkatkan kemampuan dalam berkomunikasi.

d. Hormati hak-hak pribadi anak, jangan memaksakan anak untuk menyatakan perasaannya, cara yang terbaik adalah mendengarkan apa yang akan disampaikannya dan beri mereka keberanian untuk menceritakan permasalahannya.

e. Hargai perasaan anak-anak, biarkan mereka mengalami sendiri perasaan kesal, marah dan kecewa serta biarkan mereka bercerita setelah mereka memahami perasaan tersebut atau bila mereka meminta bantuan.

Menurut Walgito, (2004: 205) di samping keterbukaan dalam komunikasi, komunikasi di dalam keluarga sebaiknya merupakan komunikasi dua arah, yaitu saling memberi dan saling menerima di antara anggota keluarga. Dengan komunikasi dua arah akan terdapat umpan balik, sehingga dengan demikian akan tercipta komunikasi hidup, komunikasi yang dinamis. Dengan komunikasi duah arah, masing-masing pihak akan aktif, dan masingmasing pihak akan dapat memberikan pendapatnya mengenai masalah yang dikomunikasikan. 
Komunikasi sebagai sarana dalam rangka mempererat hubungan diantara anggota keluarga diharapkan senantiasa berjalan dengan membuahkan hasil atau berguna, tentunya komunikasi tersebut adalah komunikasi yang efektif. Menurut Onong Uchjana Effendi, (1993: 42) komunikasi yang efektif dipengaruhi oleh dua faktor, yaitu:

\section{Faktor pada komponen komunikan (penerima informasi atau pendengar)}

Ditinjau dari komponen komunikan seorang akan dapat dan akan menerima sebuah pesan hanya kalau terdapat empat kondisi berikut :

a. Ia dapat dan benar-benar mengerti pesan komunikasi.

b. Pada saat ia mengambil keputusan, ia sadar bahwa keputusannya itu sesuai dengan tujuannya.

c. Pada saat ia mengambil keputusan, ia sadar bahwa keputusannya itu bersangkutan dengan kepentingan pribadinya.

d. Ia mampu untuk menepatinya baik secara mental maupun secara fisik.

\section{Faktor pada komponen komunikator (pengirim informasi atau pembicara)}

a. Kepercayaan kepada komunikator (source credibility), yang ditentukan oleh keahliannya dan dapat tidaknya ia dipercaya. Kepercayaan yang besar akan dapat meningkatkan daya perubahan sikap, kepercayaan yang kecil akan mengurangi daya perubahan sikap.

b. Daya tarik komunikator (source atractivitess), seorang komunikator akan mempunyai kemampuan untuk melakukan perubahan sikap melalui mekanisme daya tarik. Komunikator akan dianggap mempunyai persamaan dengan komunikan bersedia untuk tunduk kepada pesan yang dikomunikasikan komunikator.

Darlene P. Hopson dan Derek S. Hopson, (2002: 254) mengatakan bahwa teknik yang dapat membantu diantaranya orang tua bisa membahas apa yang mereka inginkan kelak mereka dewasa. Bantulah anak remaja untuk menyatakan perasaan mereka. Misalnya mereka ingin membuka diri terhadap apa dan jenis persahabatn bagaimana yang mereka ingnkan dengan orang- 
orang yang berbeda dan tetap mempertahankan komunikasi yang terbuka dengan mereka.

Ada dua sikap orang tua yang sangat mengganggu proses komunikasi dengan anak remajanya sebagaimana diungkapkan Aziz Mushaffa (2001:95), kedua sikap tersebut sebagai berikut:

Pertama, adalah sikap dan pandangan terhadap remaja yang cenderung memandang dan memperlakukan mereka seperti anak-anak yang masih berusia dibawah 12 tahun sehingga kurang memberi peluang untuk memikul tanggung jawab sesuai dengan kemampuan mereka.

Kedua, adalah sikap yang memandang para remaja sebagai orang dewasa karena terpancang pada pertumbuhan fisik yang begitu pesat, sehingga keinginan bergantung anak kepada orang tuanya tidak terpenuhi sama sekali.

\section{4) Komunikasi Keluarga Menurut Pandangan Islam}

Begitu besarnya pengaruh keluarga dalam membentuk kepribadian dan sikap anak. Sehingga perlu kiranya diciptakan kondisi keluarga yang baik. Zakiyah Darajat (1994: 47) menyatakan bahwa jika suasana dalam keluarga itu baik dan menyenangkan maka anak akan tumbuh dengan baik pula. Diantara langkah yang dapat ditempuh untuk menciptakan suasana yang baik itu adalah usaha menciptakan terwujudnya saling pengertian, saling menerima, saling menghargai dan saling menyanyangi di antara suami-istri dan seluruh anggota keluarga dan media yang digunakan untuk mewujudkan ini adalah komunikasi. Karena komunikasi dalam keluarga ini memegang peranan yang sangat vital maka hal ini tidak boleh di anggap sederhana, seperti yang di isyaratkan oleh Al Quran dalam surat At Taghabun ayat 14:

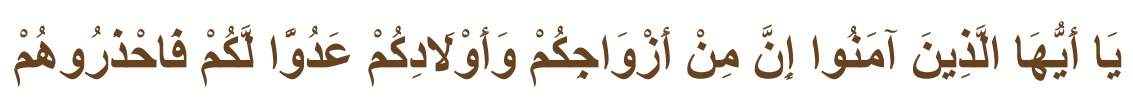

Artinya: "Hai orang- orang yang beriman, sesungguhnya di antara istriistrimu dan anak- anakmu ada yang menjadi musuh bagimu, maka berhatihatilah kamu terhadap mereka."(Q.S At Taghabun ayat 14). 
Ayat tersebut diatas dapat diambil suatu pemahaman bahwa dalam keluargapun dapat terjadi permusuhan apabila tidak terjalin komunikasi, saling pengertian dan saling memahami. Pendidikan Islam berarti optimalisasi potensi anak menuju kesempurnaan, yaitu manusia muslim yang beriman dan beramal sholeh sesuai dengaan tuntuan ajaran Islam itu tidak akan tercapai dengan baik tanpa dimulai dengan komunikasi yang baik dari sebuah keluarga.

Al Quran sebagai sumber pokok ajaran Islam telah banyak memberikan pelajaran tentang komunikasi yang baik, berikut ini sebuah contoh komunikasi yang baik yang di tampilkan Al-Quran dalam surat Ash Shaffaat ayat 102:

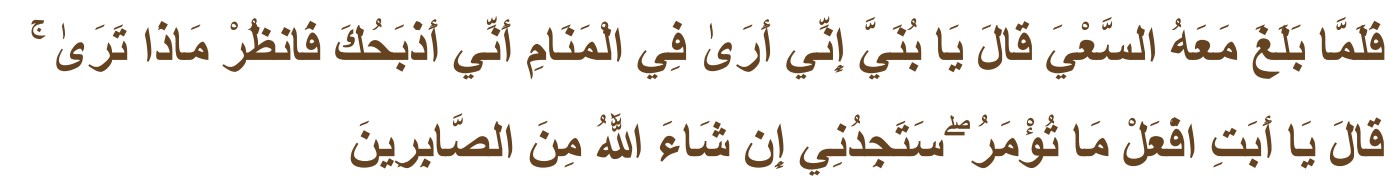

Artinya: "Maka tatkala anak itu sampai ( pada umur sanggup ) berusaha bersama-sama Ibrahim, Ibrahim berkata: Hai anakku sesungguhnya aku melihat dalam mimpi bahwa aku menyembelihmu, maka fikirkanlah apa pendapatmu,..ia menjawab, "Hai Bapakku, kerjakanlah apa telah diperintahkan kepadamu, insya Allah engkau akan mendapatiku termasuk orang yang sabar" (Q.S Ash Shaffat ayat 102).

Ayat tersebut diatas dapat dilihat betapa komunikasi sangat baik yang telah dicontohkan Nabi Ibrahim dan Ismail kepada umat Islam. Adapun inti ajaran komunikasi yang dapat diambil dari ayat ini adalah sebagai berikut:

\section{a. Terjadi Komunikasi Dua Arah}

Dari ayat tersebut di atas dengan jelas adanya pembagian kesempatan untuk menyampaikan pendapat dan pesan antara Nabi Ibrahim dan Ismail, sehingga tidak terjadi pemaksaan. Hal ini dapat dilihat dari ungkapan Nabi Ibrahim untuk meminta pendapat anaknya yaitu " Hai anakku, sesungguhnya aku melihat dalam mimpi bahwa aku menyembelihmu, maka fikirkanlah apa pendapatmu...." hal ini nampak merupakan suatu kalimat pertanyaan yang ditujukan kepada Nabi Ismail untuk memberikan pendapat atau tanggapan tentang apa yang ditugaskan kepada ayahnya, dalam hal ini Nabi Ibrahim 
tidak memaksakan kehendaknya kepada anaknya walaupun itu merupakan perintah yang harus dilaksanakan, akan tetapi beliau meminta pendapat dari anaknya tentang hal tersebut. Hal ini akan menciptakan suasana yang harmonis dalam keluarga di mana masing-masing pihak saling menghargai dan menghormati pribadi masing-masing, sehingga akan terbina rasa tanggung jawab dalam diri setiap individu anggota keluarga.

Manfaat dari komunikasi dua arah seperti contoh diatas mempunyai pengaruh yang sangat besar dalam sebuah keluarga. Misalnya dengan memberikan kesempatan kepada anak untuk mengungkapkan perasaan dan idenya, sehingga orang tua dapat mengetahui apa yang dinginkan oleh anak dan orang tua dapat memberikan arahan yang tepat dan sesuai apa yang diharapkan oleh anak. Alex Sobur (1997: 15) menyatakan bahwa komunikasi dua arah akan menumbuhkan kewibawaan orang tua, karena menurutnya ketika anak mau melakukan apa yang telah disampaikan oleh orang tua tanpa paksaan, karena sudah memahami apa yang dikehendaki orang tua, ia akan menghormati orang tuanya.

\section{b. Penggunaan Media (verbal) yang tepat}

Dalam ayat tadi diungkapkan pengungkapan kata yang sangat indah ketika Nabi Ibrahim mengajukan pertanyan kepada anaknya Ismail, ungkapan yaaang digunakan oleh Nabi Ibrahim dapat dimengerti bahkan menyentuh jiwa Ismail sebagai komunikan, sehingga Ismail merasa ikut terlibat dalam proses komunikasi yang sedang berlangsung. Hal ini dapat dilihat dari kalimat pembuka yang digunakan Nabi Ibrahim dengan menggunakan kalimat "hai anakku “ Yaitu suatu ungkapan panggilan yang menunjukan kasih sayang kepada anaknya, sehingga anaknyapun menghormati orang tuanya dengan membalas menggunakan ungkapan yang menunjukkan rasa penghormatan "hai bapakku“ Inilah sebuah contoh komunikasi antara orang tua dengan anak yang telah divisualkan secara transparan oleh Al Quran yang hendaknya menjadi tauladan bagi keluarga muslim dalam kehidupan seharihari. 
Dalam pendidikan Islam, komunikasi orang tua anak selain menggunakan metode dialog seperti di atas juga dapat dilakukan dengan menggunakan metode nasehat yang baik, karena nasehat yang baik menurut Abdullah 'Ulwan mempunyai pengaruh yang sangat besar dalam diri anak cara yang dilahirkan dengan fitrah.

\section{METODE PENELITIAN}

\section{1) Desain Penelitian}

Desain penelitian yaitu proses yang diperlukan dalam merancang penelitian dan pelaksanaan penelitian agar pertanyaan-pertanyaan yang ada bisa dijawab. Penelitian yang dilakukan disini menerapkan system kerja sama yang komprehensif antara peneliti dan masyarakat. Hasil yang nanti diperoleh adalah hasil penelitian dari kajian yang dilakukan bukan hanya oleh peneliti tetapi juga bersama-sama dengan pihak masyarakat.

Dalam penelitian ini ada beberapa langkah penelitian seperti yang disebutkan oleh Arikunto (2006: 22-23). Berkenaan langkah-langkah penelitian, yaitu: (1) menentukan masalah, (2) studi pendahuluan, (3) merumuskan masalah, (4) merumuskan kerangka pikiran, (5) menentukan variabel dan sumber data, (6) menentukan dan menyusun instrumen, (7) mengumpulkan data, (8) analisis data, (9) membuat kesimpulan, dan (10) menyusun laporan.

\section{2) Data dan Sumber Data Penelitian}

Sumber data adalah unsur utama dalam penelitian. Karena melalui sumber data ini, data-data konkrit dapat diperoleh dan dapat memberikan informasi untuk keperluan penelitian (Masri Singarimbun dan Sopian Effendi, 1999:122). Data ini ada yang primer dan sekunder. Data primer dapat diperoleh dari hasil observasi dan wawancara pribadi dengan pihak terkait, sedangkan data sekunder dapat diperoleh dari buku-buku, majalah, internet, jurnal dan sumber-sumber lainnya yang terkait dengan penelitian. Dan di dalamnya peneliti akan menggunakan pendekatan kualitatif yaitu membahas serta menganalisa kemudian menyimpulkan sebagai kesimpulan final apabila sudah memenuhi pertimbangannya. 


\section{3) Teknik Pengumpulan Data}

Teknik pengumpulan data dalam penelitian ini, menggunakan teknik pengumpulan data sebagai berikut:

a. Observasi yaitu pengamatan dan pencatatan dengan sistematis fenomenafenomena yang diselidiki (Sutrisno Hadi, 1984:141).

b. Interview (wawancara), yaitu percakapan dengan maksud tertentu. Wawancara ini dilakukan secara mendalam dan terstruktur. Susunan pertanyaan dan kata-kata dalam setiap pertanyaan dapat diperjelas pada saat wawancara berlangsung, disesuaikan dengan kebutuhan dan kondisi lapangan (Masri Singarimbun dan Sopian Effendi, 1999:61).

c. Dokumentasi, yaitu untuk mendapatkan data-data yang diperoleh dalam penelitian ini, dan untuk memperkuat hasil penelitian. Dalam hal ini diperoleh dari buku-buku, majalah, internet, jurnal dan sumber-sumber lainnya yang terkait dengan penelitian.

\section{4) Teknik Keabsahan Data}

Teknik keabsahan data dalam penelitian ini menggunakan kriteria sebagai berikut:

a. Kredibilitas (kepercayaan) dengan teknik trianggulasi yaitu teknik pemeriksaan teknik keabsahan data yang memanfaatkan sesuatu yang lain (Soetrisno Hadi, 1984:1).

b. Ketekunan dan keajegan pengamatan, yaitu menemukan ciri dan unsur yang terkait dengan situasi yang sangat relevan dengan persoalan yang sedang dicari dan memusatkan kepada hal tersebut secara rinci, (Lexy J. Moleong, 1999:329).

\section{5) Teknik Analisa Data}

Teknik analisa data adalah suatu proses mengorganisasikan dan mengurutkan data ke dalam pola dan kategori tertentu. Selanjutnya data itu di analisa secara deskriptif agar mendapatkan hasil yang objektif (Lexy J. Moleong (1999:103). Tujuannya untuk menggambarkan relasi komunikasi keluarga dalam membentuk sikap sosial remaja. Setelah data-data terkumpul 
maka langkah-langkah selanjutnya adalah analisa data yang diperoleh melalui pendekatan deskriptif kualitatif.

Penelitian kualitatif ini menghasilkan transkip wawancara, catatan lapangan, gambar, tipe rekaman dan lain sebagainya (Kristi Purwandani, 1999:22).

\section{HASIL DAN PEMBAHASAN}

\section{Komunikasi Dalam Keluarga}

Hubungan yang baik dalam sebuah keluarga adalah hubungan yang penuh pengertian dan kasih sayang, disertai dengan bimbingan dan dorongan dari orang tua. Setiap anggota keluarga harus saling menghormati, saling memperhatikan dan saling memberi tanpa harus diminta, dan juga setiap masalah harus dihadapi dan diupayakan untuk kemudian dipecahkan bersama, serta memberi kebebasan kepada anak untuk mengungkapkan pikiran dan perasaanya. Komunikasi di dalam keluarga memiliki ciri-ciri minimal adanya keterbukaan, empati, dukungan, perasaan positif, dan kesamaan.

Salah satu yang sangat penting dalam kehidupan manusia yang harus mendapat perhatian serius adalah keluarga, anak-anak dalam keluarga adalah buah hati, permata keluarga, anak-anak dalam keluarga adalah amanah Allah yang perlu dipelihara sebaik-baiknya. Demikian beberapa ungkapan masyarakat tersebar luas dalam mendudukkan anak pada tempat yang cukup mulia dan berharga, sebagaimana firman Allah dalam surat An Nisa' ayat 9 yang berbunyi:

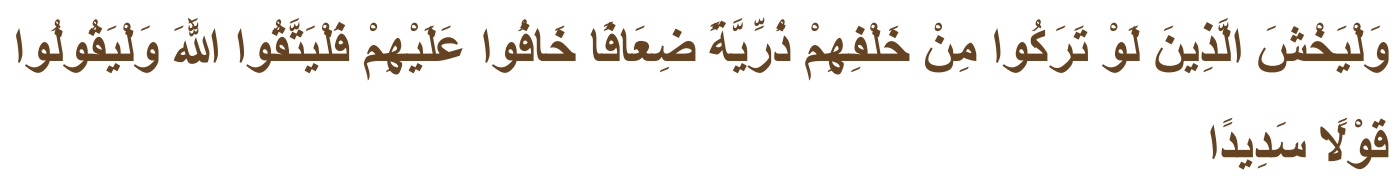

Artinya: "Dan hendaklah takut kepada Allah orang-orang yang seandainya meninggalkan dibelakang mereka anak-anak yang lemah, yang mereka khawatir terhadap (kesejahteraan) mereka. Oleh sebab itu hendaklah mereka bertakwa kepada Allah dan hendaklah mereka mengucapkan Perkataan yang benar.” (Q.S. An Nisa: 9).

The journal of social and economics education 
Keluarga adalah salah satu elemen pokok pembangunan identitas pendidikan, menciptakan proses-proses naturalisasi sosial, membentuk kepribadian-kepribadian serta memberi kebiasaan baik pada anak-anak yang akan bertahan selamanya. Dengan kata lain keluarga merupakan tempat belajar awal penyusunan sikap individu dan struktur kepribadian, melalui keluarga anak mendapatkan nilai-nilai kaidah etika dan moralitas.

\section{Sikap Sosial Anak Remaja}

Sikap adalah kesadaran individu yang menentukan perbuatan-perbuatan yang nyata ataupun yang mungkin akan terjadi didalam kegiatan-kegiatan sosial. Banyak sosiolog dan psikolog memberi batasan bahwa sikap merupakan kecenderungan individu untuk merespon dengan cara yang khusus terhadap stimulus yang ada dalam lingkungan sosial. Sikap merupakan suatu kecenderungan untuk mendekat atau menghindar, positif atau negatif terhadap berbagai keadaan sosial. Apakah itu institusi, pribadi, situasi, ide, konsep dan sebagainya.

Sikap sosial anak remaja adalah sikap sosial yang dilakukan oleh anak remaja, dimana sikap sosial merupakan tanggapan/reaksi terhadap lingkungan dalam upaya bersosialisasi dengan individu lainnya tanpa menimbulkan suatu konflik. Kita telah ketahui bahwa orang didalam berhubungan dengan orang lain tidak hanya berbuat begitu saja, tetapi juga menyadari perbuatan yang dilakukan dan menyadari pola situasi yang ada sangkut pautnya dengan perbuatan itu. Kesadaran ini tidak hanya mengenai tingkah laku yang sudah terjadi, tetapi juga tingkah laku yang mungkin akan terjadi. Sikap seseorang selalu diarahkan terhadap sesuatu hal atau suatu objek tertentu. Tidak ada satu sikap pun yang tanpa objek.

\section{Pengaruh Komunikasi dalam Keluarga Terhadap Sikap Sosial Anak Remaja}

Pembentukan dan perubahan sikap tidak terjadi dengan sendirinya. Sikap terbentuk dalam hubunganya dengan suatu objek, orang, kelompok, lembaga, nilai, melalui hubungan antar individu, hubungan didalam kelompok, 
komunikasi surat kabar, buku, poster, radio, televisi dan sebagainya, terdapat banyak kemungkinan yang pengaruhi timbulnya sikap. Lingkungan yang terdekat dengan kehidupan sehari-hari banyak memiliki peranan. Keluarga yang terdiri dari: orang tua, saudara-saudara di rumah memiliki peranan yang penting.

Sikap tumbuh dan berkembang dalam basis sosial yang tertentu, misalnya ekonomi, politik, agama dan sebagainya. Di dalam perkembangannya sikap banyak dipengaruhi oleh lingkungan, norma-norma. Hal ini akan mengakibatkan perbedaan sikap antara individu yang satu dengan yang lainnya karena perbedaan pengaruh atau lingkungan yang diterima. Sikap tidak akan terbentuk tanpa interaksi manusia terhadap objek tertentu atau suatu objek. Sikap itu dapat diubah dan dibentuk apabila terdapat hubungan timbal balik yang langsung antara manusia; adanya komunikasi (yaitu hubungan langsung) dari satu pihak. Faktor inipun masih tergantung pula adanya sumber penerangan itu memperoleh kepercayaan orang banyak/tidak, ragu-ragu atau tidaknya menghadapi fakta dan isi sikap baru itu.

Periode kritis penumbuhan sikap seseorang terjadi pada usia 12-30 tahun. Setelah usia 30 tahun sikap relatif permanen sehingga sulit berubah. Penumbuhan sikap yang paling tepat ketika usia Sekolah Menengah Pertama, sampai dengan Perguruan Tinggi, setelah itu sikap akan tumbuh melalui belajar dan pengalaman pribadi masing-masing. Perlu dipahami, bahwa dalam hidup belajar lebih banyak ditentukan oleh diri sendiri dari pada di bangku sekolah.

Tanggung jawab orang tua yang besar untuk berkomunikasi dan melatih anak-anak mereka adalah cukup penting untuk disadari karena tanpa komunikasi orang tua anak tidak dapat berkembang dengan baik dan akan mudah terpengaruh oleh lingkungan sekitar terutama dengan perkembangan teknologi yang semakin maju sehingga informasi tak dapat di bendung lagi. Informasi yang disajikan di televisi sangat berpengaruh terhadap perkembangan sikap sosial anak, karena acara yang disajikan tidak 
memperhitungkan dampak negatif yang akan diperoleh bagi anak, oleh karena itu komunikasi dan arahan orang tua sangat diperlukan.

\section{E. KESIMPULAN}

Para psikolog dan pakar pendidikan menegaskan bahwa keluarga memainkan peran terbesar dalam proses perkembangan sikap sosial anak. Tak diragukan lagi keluarga (orang tua) memiliki dampak yang sangat besar dalam pembentukan sikap dan perilaku individu melalui pendidikan. Sikap sosial dapat berkembang dengan baik karena adanya peran orang tua dalam berkomunikasi dan arahan dari orang tuanya, karena dengan komunikasi dan arahan dari orang tua anak akan dapat memilah-milah mana yang baik dan mana yang buruk.

Salah satu cara untuk menciptakan dan mengembangkan iklim komunikasi yang kondusif adalah dengan memberikan peluang kepada anak-anak, baik putra maupun putri, untuk mengungkapkan diri dan perasaan mereka. Di sinilah kuantitas komunikasi menjadi relevan. Lewat pengungkapan diri, anak-anak akan merasa bahwa mereka diperhatikan dan dibutuhkan. Hubungan yang hangat pun akan terjalin antara anak-anak dan orangtua. Ibu, khususnya punya peran penting untuk mendidik anak-anak agar mereka mampu menyesuaikan diri dengan lingkungannya.

Dipandang dari perspektif remaja sebagai anak, tidak ada risiko apa pun untuk mengungkapkan masalah-masalah yang bersifat pribadi dan sensitif kepada orangtua, bahkan sebenarnya menyehatkan mental, sementara pengungkapan-diri yang sama kepada orang lain (bahkan kawan terdekat sekalipun) selalu mengandung risiko, misalnya dimanfaatkan atau dimanipulasi oleh orang tersebut demi keuntungan atau kesenangannya.

Ringkasnya, hanya apabila orang tua memperlakukan anak-anak mereka sebagai sahabat, selain sebagai anak, mereka dapat membicarakan masalah apa pun dengan anak-anak mereka. Perasaan yang harus ditumbuhkan kepada anak, bukan hanya rasa hormat, rasa segan, atau rasa takut, tetapi juga rasa dekat dan sayang. Hal ini hanya bisa dilakukan bila orangtua cukup sering berkomunikasi dengan anak-anak. 
Dengan demikian, anak pun akan menghargai pendapat orang tua dan mematuhi nasihat mereka. Anak tidak akan terlalu menggantungkan pendapat mereka pada kelompok sebaya yang belum berpengalaman, atau dari sumber tidak resmi lainnya yang sering menyesatkan. Karena itu komunikasi orang tua, khususnya ibu dengan anak, haruslah diusahakan cukup intensif dan intim, terutama pada saat anak-anak masih kecil dan juga selagi mereka remaja.

\section{DAFTAR PUSTAKA}

Ahmadi, Abu. 2002. Psikologi Sosial. Jakarta: Rineka Cipta.

Athar, Sahid. 2003. (Penerjemah Ade Armando). Bimbingan Seks Bagi Remaja Muslim. Jakarta: Pustaka Zahra.

Cangara, Hafied. 2002. Pengantar Ilmu Komunikasi. Jakarta: Raja Grafindo Persada.

Daradjat, Zakiyah.1994. Pendidikan Islam Dalam Keluarga dan Sekolah. Bandung: Remaja Rosda Karya.

Effendy, Onong Uchjana. 1993. Ilmu Komunikasi, Teori dan Praktik. Bandung: Remaja Rosdakarya.

Gerungan, W.A. 2000. Psikologi Sosial. Bandung: Refika Aditama.

Hopson, Derek. S. Dan Darlene P. Hopson. 2002. (Penerjemah: Lala Herawati Darma). Menuju Keluarga Kompak. Bandung: Kaifa.

Rakhmat, Jalaluddin. 1994. Keluarga Muslim Dalam Masyarakat Modern. Bandung: Remaja Rosda Karya.

Liliweri, Alo. 1997. Komunikasi Antarpribadi. Citra Aditya Bakti: Bandung.

Mulyana, Deddy. 2003. Ilmu Komunikasi Suatu Pengantar. Bandung: Remaja Rosda Karya.

Mushaffa, Aziz. 2001. Untaian Mutiara Buat Keluarga. Yogyakarta: Mitra Pustaka.

Naim, Ngainun. 2011. Dasar-Dasar Komunikasi Pendidikan. Yogyakarta: ArRuzz Media.

Sarwono, Sarlito Wirawan. 2000. Teori-Teori Psikologi Sosial. Jakarta: RajaGrafindo Persada.

Sobur, Alex. 1997. Komunikasi Orangtua dan Anak. Bandung: Angkasa.

The journal of social and economics education 
Widjaya, A.W. 1997. Komunikasi (Komunikasi dan Hubungan masyarakat). Jakarta: Bumi Aksara.

Walgito, Bimo. 2004. Bimbingan \& Konseling di Sekolah. Yogyakarta: Andi Offset. 